\title{
PENERAPAN MANAJEMEN KURIKULUM PADA KELAS UNGGULAN
}

\author{
Weti Susanti \\ wetisusanti82@gmail.com \\ Universitas Islam Negeri Imam Bonjol Padang
}

\begin{abstract}
ABSTRAK
Penelitian ini untuk mengkaji "Penerapan manajemen kurikulum pada kelas unggulan" dan mengetahui Program kelas unggulan dirancang yang berdasarkan konsep dan sistem pembelajaran yang mengedepankan upaya penggalian potensi dan bakat serta minat setiap siswa yang beraneka ragam (individual differences based learning) secara khusus untuk diberikan pelayanan pendidikan secara komprehensif, efektif dan terarah. Kelas unggulan ini dibentuk secara khusus dan berkarakteristik, mulai dari penyeleksian siswa, pembelajaran, cakupan pelajaran, nilai kriteria ketuntasan minimal (KKM) yang lebih tinggi, jam pelajaran, jumlah siswa dalam kelas dan fasilitas kelas yang disediakan dengan tujuan pelayanan proses pembelajaran untuk peserta didik yang mempunyai potensi, minat dan bakat yang lebih agar berkembang secara optimal dalam proses kegiatan belajar mengajar (KBM). Faktor pendukung yang utama dalam penerapan manajemen kurikulum kelas unggulan di Sekolah/madrasah adalah kerja sama tim pengembang kurikulum dan kerja sama antarguru dalam wadah MGMP, jenjang pendidikan guru kelas unggulan yang sesuai dengan jurusan mata pelajaran yang diajarkan, peranan komite sekolah/madrasah yang proaktif, dan ketersediaan sarana dan prasarana yang memadai. Faktor penghambat penerapan manajemen kurikulum kelas unggulan adalah tanggung jawab akademik tenaga pengajar yang masih kurang, motivasi guru yang mengajar pada kelas unggulan, kesiapan siswa secara psikologis mengikuti pembelajaran, dan kurangnya pengawasan dari dewan pakar Sekolah/madrasah terhadap pelaksanaan kurikulum di kelas unggulan.
\end{abstract}

Kata Kunci: Manajemen Kurikulum, dan Kelas Unggulan.

Salah satu bagian dari manajemen lembaga pendidikan adalah manajemen kurikulum. Kurikulum perlu dikelola dengan pertimbangan bahwa kurikulum menempati posisi sentral dalam keseluruhan proses pendidikan. Hal ini bermakna kurikulum merupakan sesuatu yang sangat strategis untuk mengendalikan jalannya proses pendidikan.

Dalam beberapa literatur disebutkan bahwa keberhasilan manajemen kurikulum tidak terlepas dari pelaksanaan Manajemen Vol 3 No 1 (2019): JPPI Volume 3 Nomor 1 Juni 2019
Berbasis Sekolah (MBS), ${ }^{1}$ yaitu suatu model manajemen yang memberikan otonomi lebih besar kepada sekolah dan mendorong pengambilan keputusan bersama atau partisipatif dari semua warga sekolah dan masyarakat untuk mengelola sekolah dalam rangka meningkatkan mutu pendidikan berdasarkan kebijakan pendidikan naisonal. ${ }^{2}$

1 Rusman, Manajemen Kurikulum, cet. 3 (Jakarta: Rajawali Pers, 2011), h. 2.

2 Departemen Pendidikan Nasional, Halaman 42 
Selanjutnya, konsep manajemen berbasis sekolah selanjutnya berkembang menjadi Manajemen Peningkatan Mutu Berbasis Sekolah (MPMBS). ${ }^{3}$

Pelaksanaan manajemen berbasis sekolah diawali dengan diterapkannya Undang-Undang Republik Indonesia Nomor 22 Tahun 1999 tentang Otonomi Daerah dan Peraturan Pemerintah Nomor 25 Tahun 2000 tentang Pembagian Wewenang antara Pemerintah Pusat dan Daerah. Undang-Undang tersebut kemudian direvisi dan disempurnakan menjadi UndangUndang Republik Indonesia Nomor 32 Tahun 2004 tentang Pemerintahan Daerah. Konsekuensi logis dari Undang-Undang dan Peraturan Pemerintah tersebut adalah manajemen pendidikan harus disesuaikan dengan jiwa dan semangat otonomi. ${ }^{4}$

Pola-pola manajemen dalam dunia pendidikan mengalami perubahan, dimensi perubahan pola-pola manajemen misalnya, dari pola subordinasi menuju pola otonomi, pola pengambilan keputusan terpusat menuju pola pengambilan keputusan partisipatif, dan lain sebagainya. ${ }^{5}$ Perubahan pola-pola tersebut diharapkan mampu mengarahkan sekolah atau sekolah/madrasah menuju kemandirian.

Qomar memberikan empat kategori dalam menggambarkan keadaan manajemen di sekolah atau sekolah/ madrasah sebagai berikut: Pertama, ada

Manajemen Berbasis Sekolah (Jakarta: Dirjen Dikdasmen Direktorat Tenaga Kependidikan, 2003), h. 5.

3 Bedjo Sujanto, Guru Indonesia dan Perubahan Kurikulum (Jakarta: Sagung Seto, 2007), h. 5.

4 Ali Idrus, Manajemen Pendidikan Global: Visi, Aksi dan Adaptasi (Jakarta: Gaung Persada Press, 2009), h. 124.

${ }^{5}$ Umaedi, Manajemen Peningkatan Mutu Berbasis Sekolah (Jakarta: Direktorat Jenderal Pendidikan Dasar dan Menengah, 2001), h. 7-8. sekolah atau sekolah/madrasah yang awalnya mengalami kemunduran, kemudian bisa maju dengan pesat. Kedua, ada sekolah atau sekolah/madrasah yang awalnya maju tetapi kemudian hampir gulung tikar. Ketiga, ada sekolah atau sekolah/madrasah yang awalnya maju dan tetap bertahan. Dan keempat, ada juga sekolah atau sekolah/madrasah yang awalnya termasuk dalam kategori tidak mengalami kemajuan dan tetap seperti itu. Menurut Qomar, empat keadaan ini lebih karena faktor manajemen daripada faktor lainnya, meskipun faktor manajemen bukanlah faktor tunggal yang terlepas dari faktor-faktor lainnya. ${ }^{6}$

Menurut hemat penulis, strategi pengelolaan proses pembelajaran merupakan bagian dari kinerja sekolah yang menjadi salah satu indikator manajemen peningkatan mutu berbasis sekolah. Dengan demikian, apa yang dikemukakan oleh Qomar merupakan bagian dari manajemen peningkatan mutu berbasis sekolah.

Pembelajaran yang dilakukan pada kelas unggulan merupakan pembelajaran yang diberikan kepada peserta didik yang memiliki potensi bakat dan intelektual istimewa. Peserta didik dinyatakan berhak mengikuti pembelajaran pada kelas unggulan setelah dinyatakan lulus seleksi. Oleh karena itu, peserta didik pada kelas unggulan memiliki keberbakatan lebih dalam pembelajaran dibandingkan peserta didik pada program kelas reguler (nonunggulan). Mengenai hal ini, Munandar menegaskan bahwa satu hal yang tidak boleh dilupakan adalah keberbakatan tidak akan muncul apabila kegiatan belajar terlalu mudah dan tidak mengandung tantangan bagi anak berbakat sehingga kemampuan mereka yang unggul tidak akan tampil. ${ }^{7}$

\footnotetext{
${ }^{6}$ Mujamil Qomar, Manajemen Pendidikan Islam (Jakarta: Erlangga, 2007), h. 3.

7 Utami Munandar (ed.), Pengembangan Kreativitas Anak Berbakat, cet. 3 (Jakarta:
} 
Dari kutipan di atas, penulis menyimpulkan bahwa pembelajaran pada kelas unggulan memiliki dimensi praktis yang berbeda dengan pembelajaran pada kelas reguler. Pembelajaran kelas unggulan memiliki tingkat kesukaran dan tantangan yang lebih dari pada pembelajaran kelas reguler. Konsekuensi logisnya adalah perangkat pembelajaran untuk kelas unggulan memiliki isi (content) kurikulum yang lebih rumit dibanding isi yang digunakan pada kelas reguler. Misalnya, pada materi pembelajaran yang sama, indikator kompetensi yang digunakan untuk kelas unggulan lebih banyak dari pada indikator yang digunakan pada kelas reguler.

Oleh sebab itu, manajemen kurikulum menjadi penting untuk diteliti karena manajemen kurikulum berhubungan dengan pelaksanaan manajemen peningkatan mutu berbasis sekolah. Menurut Qomar, manajemen kurikulum sebenamya menekankan pada strategi pengelolaan proses pembelajaran secara efektif dan efisien untuk mencapai hasil pendidikan secara maksimal. ${ }^{8}$

\section{Pembahasan}

\section{Konsep Manajemen}

\section{a. Pengertian Manajemen}

Manajemen berasal dari kata to manage yang berarti mengatur, mengurus atau mengelola. Makna manajemen secara substantif mengandung unsur-unsur kegiatan yang bersifat pengelolaan. ${ }^{9}$ Terry sebagaimana dikutip oleh Hasibuan, menyatakan bahwa manajemen adalah, "suatu proses yang khas yang terdiri dari tindakan-tindakan perencanaan, pengorganisasian, pengarahan, dan pengendalian yang dilakukan untuk menentukan serta

Departemen Pendidikan Nasional bekerja sama dengan Rineka Cipta, 2009), h. 139

${ }^{8}$ Mujamil Qomar, Manajemen Pendidikan Islam (Jakarta: Erlangga, 2007), h. 161.

9 Anton Athoillah, Dasar-Dasar Manajemen (Bandung: Pustaka Setia, 2010), h. 13 mencapai sasaran-sasaran yang telah ditentukan melalui pemanfaatan sumberdaya manusia dan sumber-sumber lainnya."10 Hersey dan Blanchard sebagaimana dikutip oleh Syafaruddin, mengemukakan bahwa aktivitas manajemen adalah: Proses bekerjasama antara individu dan kelompok serta sumberdaya lainnya dalam mencapai tujuan organisasi. Dengan kata lain, aktivitas manajerial hanya ditemukan dalam wadah sebuah organisasi, baik organisasi bisnis, pemerintahan, sekolah, industri, rumah sakit, dan lain-lain. Proses di sini menghadirkan berbagai fungsi dan aktivitas yang dilaksanakan oleh manajer dan anggota atau bawahannya dalam suatu organisasi. ${ }^{11}$

Pidarta menyatakan bahwa manajemen pada suatu organisasi terletak pada kegiatan-kegiatan awal yaitu mencakup apa yang perlu dipersiapkan, jalan mana yang akan ditempuh, kalau ada rintangan tertentu bagaimana cara mengatasinya, dan sejenisnya, serta apa yang menjadi bukti bahwa aktivitas organisasi sudah sampai pada tujuan. $^{12}$

Selanjutnya, Muhaimin,. mengemukakan bahwa manajemen adalah, "seni dan ilmu mengelola sumberdaya untuk mencapai tujuan secara efektif dan efisien. Manajemen dapat juga didefinisikan sebagai proses perencanaan, pengorganisasian, pengarahan, dan pengendalian sumberdaya untuk mencapai tujuan secara efektif dan efisien." ${ }^{\text {13 }}$

10 Malayu S.P. Hasibuan, Manajemen: Dasar, Pengertian, dan Masalah (Jakarta: Bumi Aksara, 2006), h. 2.

11 Syafaruddin, Manajemen Lembaga Pendidikan Islam (Jakarta: Ciputat Press, 2005), h. 67

12 Made Pidarta, Manajemen Pendidikan Indonesia, cet. 1 (Jakarta: Rineka Cipta, 2011), h. 16

13 Muhaimin, et.al., Manajemen 
Danim dan Suparno menyatakan bahwa manajemen adalah, "suatu proses menyelesaikan aktivitas dengan atau melalui orang lain dan berkaitan dengan rutinitas tugas suatu organisasi."14 Efektifitas dan efisiensi merupakan norma (nilai) dalam proses manajemen yang dapat dipergunakan untuk mengukur berhasil tidaknya sebuah organisasi. Maka untuk mengetahui tingkat efektifitas dan efisiensi tersebut, pengalaman masa lalu organisasi tersebut hendaknya dijadikan tempat berpijak utama untuk mengukur tingkat efektifitas dan efisiensi.

Dari beberapa pandangan mengenai manajemen di atas, penulis menyimpulkan bahwa manajemen merupakan suatu proses perencanaan, pengorganisasian, pelaksanaan, dan evaluasi dengan memanfaatkan sumberdaya yang dimiliki pada suatu organisasi untuk mencapai tujuan secara efektif dan efisien. Manajemen berhubungan erat dengan lima hal utama, yaitu: 1) organisasi sebagai wadah untuk perwujudan manajemen; 2) manajer; 3) anggota organisasi; 4) tujuan organisasi; dan 5) efektivitas dan efisiensi.

\section{b. Fungsi Manajemen}

Kegiatan manajemen mencakup pengkajian yang sangat luas, sebab aktivitas manajemen dimulai dari bagaimana menentukan arah organisasi di masa depan, menciptakan kegiatan-kegiatan organisasi, mendorong terbinanya kerjasama antara sesama anggota organisasi, serta mengawasi kegiatan dalam mencapai suatu tujuan.

Pendidikan: Aplikasinya dalam Penyusunan Rencana Pengembangan Sekolah/Madrasah, cet. 3 (Jakarta: Kencana, 2011), h. 4-5.

14 Sudarwan Danim dan Suparno, Manajemen dan Kepemimpinan Transformasional Kekepalasekolahan (Jakarta: Rineka Cipta, 2009), h. 3.
Proses atau fungsi manajemen sekolah atau lembaga pendidikan pada dasarnya tidak berbeda dengan fungsi-fungsi manajemen pada umumnya, kalaupun ada perbedaan itu tidak terletak pada substansinya tetapi pada praktik pelaksanaan fungsi-fungsi tersebut karena dipengaruhi oleh jenis, tipe, dan karakteristik organisasi serta manajer dan anggota (karyawan organisasi). ${ }^{15}$

Fayol sebagaimana dikutip oleh Winardi, menyatakan bahwa terdapat lima fungsi manajemen, yaitu: perencanaan (planning), pengorganisasian (organizing), pengarahan (commanding), koordinasi (coordinating), dan pengawasan (controlling). ${ }^{16}$ Gorton sebagaimana dikutip oleh Bafadal mengemukakan langkahlangkah manajemen secara terperinci. Menurut Gorton langkah- langkah manajemen meliputi: 1) identifikasi masalah; 2) diagnosis masalah; 3) penetapan tujuan; 4)pembuatan keputusan; 5)perencanaan; 6)pengorganisasian; 7)pengkoordinasian; 8)pendelegasian; 9)penginisiasian; 10)pengkomunikasian; 11)kerja dengan kelompok-kelompok; dan 12) penilaian. ${ }^{17}$

Penulis menyimpulkan bahwa fungsi- fungsi manajemen meliputi fungsi perencanaan (planning), pengorganisasian (organizing), pelaksanaan (actuating), dan pengevaluasian (evaluating). Kesimpulan ini didapat setelah menganalisis pendapat para ahli di atas tentang fungsi- fungsi manajemen. Para ahli memberikan hirarki

${ }^{15}$ Marno, Islam by Management and Leadership (Jakarta: Lintas Pustaka Publisher, 2007), h. 17.

${ }^{16}$ Winardi, Kepemimpinan Dalam Manajemen (Jakarta: Rineka Cipta, 2000), h. 161.

${ }^{17}$ Ibrahim Bafadal, Manajemen Peningkatan Mutu Sekolah Dasar dari Sentralisasi Menuju Desentralisasi (Jakarta: Bumi Aksara, 2003), h. 40. 
yang sama pada fungsi perencanaan (planning) dan pengorganisasian (organizing). Selanjutnya, terdapat perbedaan pendapat para ahli tentang fungsi manajemen setelah fungsi pengorganisasian (organizing). Ada yang memasukkan fungsi koordinasi (coordinating), fungsi pembiayaan (funding), fungsi pengarahan (commanding), dan sebagainya. Akan tetapi pada fungsi akhir, para ahli memberikan pendapat yang sama, yaitu adanya fungsi penilaian (evaluating/ controlling). Oleh penulis, beberapa fungsi yang berbeda tersebut digolongkan ke dalam fungsi pelaksanaan (actuating), sehingga diperoleh kesimpulan sebagaimana tersebut di atas.

\section{c. Fungsi Perencanaan (planning)}

Merencanakan pada dasarnya menentukan kegiatan yang hendak dilakukan pada masa depan. Kegiatan ini dimaksudkan untuk mengatur berbagai sumberdaya agar hasil yang dicapai sesuai dengan yang diharapkan. Dalam perencanaan terdapat tiga kegiatan, yaitu: 1) perumusan tujuan yang ingin dicapai; 2) pemilihan program untuk mencapai tujuan; dan 3) identifikasi dan pengerahan sumber yang jumlahnya selalu terbatas. Di dalam perencanaan ditentukan tujuan atau sasaran yang hendak dicapai dan menetapkan jalan dan sumber yang diperlukan untuk mencapai tujuan seefisien dan seefektif mungkin. ${ }^{18}$

Perencanaan merupakan tindakan awal dalam aktivitas manajerial pada setiap organisasi. Karena itu perencanaan akan menentukan adanya perbedaan kinerja satu organisasi dengan organisasi lain dalam pelaksanaan rencana untuk mencapai tu-

\footnotetext{
${ }^{18}$ Fattah, Landasan Manajemen Pendidikan, op. cit., h. 49.
}

juan. Perencanaan berkaitan dengan tujuan (means) dan sasaran yang dilakukan (ends). ${ }^{19}$ Perencanaan merupakan pembentukan struktur peran-peran yang mendukung pencapaian tujuan yang akan diperankan oleh orang- orang dalam organisasi. $^{20}$

Dengan demikian dapat dipahami bahwa pada fungsi perencanaan terdapat pengambilan keputusan yang diambil untuk melakukan tindakan selama waktu tertentu agar tercapai tujuan yang efektif dan efisien. Bahkan pada tingkat puncaknya, pengambilan keputusan berada pada pengambilan keputusan stratejik. J. Salusu menyatakan bahwa keputusan stratejik dibuat oleh pembuat keputusan tingkat tinggi guna mencapai tujuan, sasaran tertentu dengan memperhitungkan kemampuan internal, nilai, dan mengandung makna persaingan atau kompetisi. $^{21}$

\section{d. Fungsi Pengorganisasian (organi- zing)}

Fungsi pengorganisasian merupakan proses pembentukan struktur organisasi. Struktur organisasi merupakan kerangka formal organisasi di mana tugas-tugas ditentukan, dikelompokkan, dan dikoordinasikan. Fattah mendefinisikan pengorganisasian sebagai proses membagi kerja ke dalam tugastugas yang lebih kecil, membebankan tugas-tugas itu kepada orang yang sesuai dengan kemampuannya, dan mengalokasikan sumberdaya, serta mengkoordinasikannya dalam rangka efektivitas pen-

${ }^{19}$ Syafruddin, Manajemen, op. cit., h. 61.

20 Nana Syaodih Sukmadinata, et.al., Pengendalian Mutu Pendidikan Sekolah Menengah (Bandung: Refika Aditama, 2006), h. 37.

21 J. Salusu, Pengambilan Keputusan Stratejik untuk Organisasi Publik dan Organisasi Nonprofit, cet. 4 (Jakarta: Grassindo, 2002), h. 117. 
capaian tujuan organisasi.

Untuk kelangsungan fungsi organisasi ada beberapa prinsip dalam rancangan manajemen, yaitu: (1) kesatuan perintah; (2) rentang pengawasan; (3) pembagian kerja; dan (4) departementalisasi. Dalam pengorganisasian terdapat penciptaan hubungan tugas yang jelas antara personalia, sehingga dengan demikian setiap orang dapat bekerja sama dalam kondisi yang baik untuk mencapai tujuan- tujuan organisasi. Winardi sebagaimana dikutip oleh Syafaruddin mengemukakan bahwa fungsi pengorganisasian dapat menentukan: (1) siapa yang akan melakukan apa; (2) siapa memimpin siapa; (3) saluran- saluran komunikasi; dan (4) memusatkan sumber- sumber data terhadap sasaran- sasaran. $^{22}$

Dengan demikian dapat dipahami bahwa fungsi pengorganisasian (organizing) berhubungan dengan pembagian tugas sesuai dengan kapasitas sumber daya yang dimiliki guna mencapai tujuan organisasi.

\section{e. Fungsi Pengawasan (controlling)}

Pengawasan (controlling) merupakan tindakan meneliti dan mengawasi agar semua tugas dilakukan dengan baik dan sesuai dengan peraturan yang ada atau sesuai dengan deskripsi tugas masingmasing personal. Pengendalian dapat dilakukan atasan kepada bawahannya atau pula bawahan dapat melakukan upaya kritik kepada atasannya. ${ }^{23}$

Pengawasan merupakan tindakan terakhir yang dilakukan para manajer pada suatu organisasi. Dengan pengawasan diharapkan penyimpangan dalam berbagai cit., h. 113.
${ }^{22}$ Syafaruddin, Manajemen, op. cit., h. 82.

${ }^{23}$ Athoillah, Dasar-Dasar Manajemen, op. hal dapat dihindari sehingga tujuan dapat tercapai. Apa yang direncanakan dijalankan dengan benar sesuai hasil musyawarah dan pendayagunaan sumberdaya material akan mendukung terwujudnya tujuan organisasi. Proses pengawasan yang akan menjamin standar bagi pencapaian tujuan. $^{24}$

Dengan demikian dapat dipahami bahwa fungsi pengawasan (controlling) berhubungan dengan wewenang manajer atas sebagai pengambil keputusan sekaligus penilai terhadap efisiensi dan efektivitas pelaksanaan tugas pada suatu organisasi. Manajer pada level ini memiliki peran dominan dalam pengawasan semua tugas yang dilaksanakan oleh bawahan.

\section{Konsep Kurikulum}

\section{a. Pengertian Kurikulum}

Istilah kurikulum berasal dari bahasa latin, yaitu curriculae, artinya jarak yang harus ditempuh oleh seorang pelari. Pada waktu itu, pengertian kurikulum ialah jangka waktu pendidikan yang harus ditempuh oleh siswa yang bertujuan untuk memperoleh ijazah. Dengan menempuh suatu kurikulum, siswa dapat memperoleh ijazah. Dalam hal ini, ijazah pada hakikatnya merupakan suatu bukti bahwa siswa telah menempuh kurikulum yang berupa rencana pelajaran, sebagaimana halnya seorang pelari telah menempuh suatu jarak antara satu tempat ke tempat yang lainnya dan akhirnya mencapai garis akhir (finish). ${ }^{25}$

$$
\text { Undang-Undang Republik }
$$

Indonesia Nomor 20 Tahun 2003 tentang Sistem Pendidikan Nasional pada bab I pasal 1 ayat (19)

$$
{ }^{24} \text { Syafaruddin, Manajemen, op. cit., h. }
$$

110.

${ }^{25}$ Oemar Hamalik, Kurikulum dan Pembelajaran, cet. 8 (Jakarta: Bumi Aksara, 2008), h. 16. 
menyatakan bahwa, "kurikulum merupakan seperangkat rencana dan pengaturan mengenai tujuan, isi, dan bahan pelajaran serta cara yang digunakan sebagai pedoman penyelenggaraan kegiatan pembelajaran untuk mencapai tujuan pendidikan tertentu." 26

Definisi kurikulum di atas merupakan definisi baku yang selanjutnya dijadikan acuan dalam memahami makna kurikulum dalam perspektif pendidikan nasional. Definisi kurikulum dalam undang-undang tersebut dimaknai secara luas, tidak dalam pemaknaan kurikulum secara sempit, yaitu terbatas pada mata pelajaran yang harus disampaikan (what to teach ). Kurikulum tingkat satuan pendidikan dikembangkan sesuai dengan satuan pendidikan, potensi sekolah/ daerah, karakteristik sekolah/ daerah, sosial budaya masyarakat setempat, dan karakteristik peserta didik. $^{27}$

Berdasarkan pendapat para ahli di atas, penulis menyimpulkan bahwa kurikulum merupakan rancangan aktivitas yang ditentukan guna memperoleh hasil pendidikan sebagaimana tujuan yang ditetapkan. Berdasarkan proses pengembangannya dan ruang lingkup penggunaannya, kurikulum dapat dibedakan ke dalam tiga kategori. Pertama, kurikulum nasional, yaitu kurikulum yang disusun oleh tim pengembang tingkat nasional dan digunakan secara nasional. Kedua, kurikulum negara bagian, yaitu kurikulum yang disusun oleh masing-

${ }^{26}$ Undang-Undang Republik Indonesia Nomor 20 Tahun 2003 bab I pasal 1 ayat (19).

${ }^{27}$ E. Mulyasa, Kurikulum Tingkat Satuan Pendidikan, cet. 2 (Bandung: Remaja Rosdakarya, 2007), h. 8. masing negara bagian. Ketiga, kurikulum sekolah, yaitu kurikulum yang disusun oleh satuan pendidikan sekolah. Kurikulum tingkat satuan pendidikan merupakan kurikulum sekolah. Kurikulum sekolah lahir dari keinginan untuk melakukan diferensiasi dalam kurikulum.

Pandangan atau anggapan yang sampai saat ini masih lazim dipakai dalam dunia pendidikan dan persekolahan di Indonesia, yaitu kurikulum sebagai suatu rencana tertulis yang disusun guna memperlancar proses pembelajaran. Hal ini sesuai dengan rumusan pengertian kurikulum seperti yang tertera dalam Undang-Undang Republik Indonesia Nomor 20 Tahun 2003 tentang Sistem Pendidikan Nasional bab I pasal 1 ayat (19) dinyatakan bahwa, "kurikulum adalah seperangkat rencana dan pengaturan mengenai tujuan, isi, dan bahan pelajaran serta cara yang digunakan sebagai pedoman penyelenggaraan kegiatan pembelajaran untuk mencapai tujuan pendidikan tertentu."

Dalam panduan penyusunan kurikulum tingkat satuan pendidikan (KTSP) jenjang pendidikan dasar dan menengah yang dikeluarkan oleh Badan Standar Nasional Pendidikan (BSNP), pengertian kurikulum yang digunakan mengacu pada pengertian seperti yang tertera dalam undangundang tersebut. Secara lebih jelas, kurikulum tingkat satuan pendidikan adalah kurikulum operasional yang disusun oleh dan dilaksanakan di masingmasing satuan pendidikan. Kurikulum tingkat satuan pendidikan terdiri dari tujuan pendidikan tingkat satuan pendidikan, struktur dan muatan kurikulum tingkat 
satuan pendidikan, kalender pendidikan, dan silabus. $^{28}$

Dengan bertolak dari pengertian- pengertian seperti di atas pada akhirnya menempatkan kurikulum sebagai sesuatu yang sangat dominan dan penting dalam kegiatan sekolah karena kurikulum sebagai rencana sekolah dalam arti luas berarti mencakup makna manajemen. Segalanya harus direncanakan dan diciptakan untuk kepentingan dan kemajuan sekolah dan peserta didik. Oleh karena itu, salah satu dari implikasi dianutnya makna kurikulum modern oleh sekolah dan peserta didik agar pihak-pihak tertentu yang menentukan program sekolah dapat menempatkan kurikulum sebagai kunci dalam pengembangan manajemen dan perencanaan sekolah. Hal ini perlu ditegaskan karena pada dasarnya inti kegiatan atau proses pendidikan adalah terletak pada kurikulum.

\section{b. Fungsi Kurikulum}

Pada dasarnya fungsi kurikulum identik dengan pengertian kurikulum itu sendiri. Berdasarkan pengertian kurikulum dalam arti luas, fungsi kurikulum dapat dikelompokkan sebagai berikut.

1) Sebagai pedoman penyelenggaraan pendidikan pada suatu tingkatan lembaga pendidikan tertentu dan untuk memungkinkan pencapaian tujuan lembaga pendidikan.

2) Sebagai batasan dari program kegiatan yang akan dijalankan pada

28 Siskandar, Kurikulum Tingkat Satuan

Pendidikan (Jakarta: Direktorat Jenderal Peningkatan Mutu Pendidik dan Tenaga Kependidikan Depdiknas, 2008), h. 9. suatu semester, kelas maupun pada tingkat pendidikan.

3) Sebagai pedoman guru dalam menyelenggarakan proses belajar mengajar sehingga kegiatan yang dilakukan guru dengan murid menjadi terarah kepada tujuan yang ditentukan. ${ }^{29}$

Dari uraian di atas dapat disimpulkan bahwa kurikulum berfungsi dalam menjamin keberlangsungan dan keterlibatan pemangku kepentingan (stakeholder) dalam aktivitas pendidikan guna mencapai tujuan yang telah ditentukan. Guru, kepala sekolah, masyarakat berhubungan langsung dengan fungsi kurikulum.

\section{c. Manajemen Kurikulum}

Manajemen kurikulum adalah suatu sistem pengelolaan kurikulum yang kooperatif, komprehensif, sistemik, dan sistematik dalam rangka mewujudkan ketercapaian tujuan kurikulum. Dalam pelaksanaannya, manajemen kurikulum harus dikembangkan sesuai dengan konteks manajemen berbasis sekolah dan kurikulum tingkat satuan pendidikan. Oleh karena itu, otonomi yang diberikan pada lembaga pendidikan atau sekolah dalam mengelola kurikulum secara mandiri dengan memprioritaskan kebutuhan dan ketercapaian sasaran dalam visi dan misi lembaga pendidikan atau sekolah tidak mengabaikan kebijaksanaan nasional yang telah ditetapkan. $^{30}$

Manajemen kurikulum merupakan bagian integral dari kurikulum tingkat satuan pendidikan dan manajemen berbasis

29 Oemar Hamalik, Dasar-Dasar Pengembangan Kurikulum, cet. 3 (Bandung: Remaja Rosdakarya, 2009), h. 18.

${ }^{30}$ Rusman, Manajemen Kurikulum, cet. 3 (Jakarta: Rajawali Pers, 2011), h. 3. 
sekolah. Rusman menyatakan bahwa lingkup manajemen kurikulum meliputi perencanaan, pengorganisasian, pelaksanaan dan evaluasi kurikulum. Pada tingkat satuan pendidikan kegiatan kurikulum lebih mengutamakan untuk merealisasikan dan merelevansikan antara kurikulum nasional (standar kompetensi dan kompetensi dasar) dengan kebutuhan daerah dan kondisi sekolah, sehingga kurikulum merupakan kurikulum yang integritas dengan peserta didik maupun dengan lingkungan dimana sekolah itu berada. ${ }^{31}$

Idrus menyatakan bahwa dalam pelaksanaan manajemen berbasis sekolah, pelimpahan wewenang yang menjadi otonomi sekolah meliputi:

1) Pengetahuan (knowledge); otoritas keputusan yang berkaitan dengan kurikulum, tujuan dan sasaran pendidikan.

2) Teknologi (technology); otoritas mengenai sarana dan prasarana pembelajaran.

3) Kekuasaan (power); kewenangan dalam membuat keputusan.

4) Material (material); kewenangan mengenai penggunaan fasilitas, pengadaan dan peralatan alat-alat sekolah.

5) Manusia (people); kewenangan atas keputusan mengenai sumberdaya manusia, pengembangan profesionalisme dan dukungan terhadap proses pembelajaran.

6) Waktu (time); kewenangan mengalokasikan waktu.

7) Keuangan (financial); kewenangan dalam mengalokasikan dana pendidikan.

Kepala sekolah sebagai juru

${ }^{31}$ Ali Idrus, Manajemen Pendidikan Global: Visi, Aksi dan Adaptasi (Jakarta: Gaung Persada Press, 2009), h. 26 kunci bertanggungjawab sangat besar dalam hal ini, berikut wakil kepala sekolah bidang kurikulum harus mampu mengelola pengalaman belajar dengan sebaik-baiknya. Sedangkan guru-guru yang menduduki posisi strategis dituntut memiliki kemampuan yang dapat mengubah pengalaman dari para siswa. Kepala sekolah bertanggungjawab pada segi edukatifnya melalui kepemimpinan dan memberi supervisi pengajaran, sedangkan wakil kepala sekolah sebagai pengelola pengajaran bertanggungjawab pada segi administratifnya. $^{32}$

Syafaruddin menklasifikasikan tahapan dalam manajemen kurikulum sebagai berikut. Tahap perencanaan meliputi: 1) menjabarkan GBPP menjadi analisis mata pelajaran (AMP); 2)menghitung hari kerja efektif dan jam pelajaran efektif untuk setiap mata pelajaran, hari libur, hari untuk ulangan, dan hari-hari tidak efektif; 3) menyusun Program Tahunan (Prota); 4) menyusun Program Satuan Pelajaran (PSP); dan 5) menyusun Rencana Pengajaran (RP). Tahap pengorganisasian dan koordinasi meliputi: 1) pembagian tugas mengajar dan tugas-tugas lain perlu dilakukan secara merata, sesuai dengan bidang keahlian dan minat guru; 2) penyusunan jadwal pelajaran diupayakan agar guru mengajar maksimal 5 hari per minggu, sehingga ada satu hari tidak mengajar untuk pertemuan MGMP; 3) penyusunan jadwal kegiatan perbaikan dan pengayaan; 4) Penyusunan jadwal kegiatan ekstrakurikuler; dan 5) penyusunan jadwal penyegaran guru. Pada tahap pelaksanaan,

32 Djam'an Satori dan Suryadi, “Teori Administrasi Pendidikan,” dalam Muhammad Ali, Ilmu dan Aplikasi Pendidikan, cet. 3 (Bandung: Imperial Bhakti Utama, 2009), h. 165-166. 
tugas utama kepala sekolah adalah melakukan supervisi untuk membantu guru menemukan dan mengatasi kesulitan yang dihadapi. Dengan cara ini, guru merasa didampingi pimpinan sehingga bisa meningkatkan semangat kerja. Tahap pengendalian atau pengawasan meliputi: 1) kepala sekolah perlu mengingatkan para guru bahwa evaluasi memiliki tujuan ganda, yaitu untuk mengetahui pencapaian tujuan pembelajaran khusus (TPK) dan mengetahui kesulitan siswa; 2) hasil evaluasi harus benar-benar dimanfaatkan guru untuk memperbaiki kegiatan pembelajaran. ${ }^{33}$

Dari uraian di atas penulis berpendapat bahwa tahapan-tahapan manajemen kurikulum meliputi tahapan perencanaan, pengorganisasian dan pengkoordinasian, pelaksanaan, dan pengendalian. Adapun tahapan evaluasi penulis kategorikan ke dalam tahapan pengendalian. Hal ini karena cakupan tahapan pengendalian lebih luas daripada evaluasi. Alasan lain adalah bahwa dalam tahapan pengendalian terdapat tahapan tindak lanjut terhadap hasil evaluasi. Selanjutnya, penulis berpendapat bahwa manajemen kurikulum merupakan kegiatan manajerial yang pelaksanaannya secara otonom dilimpahkan kepada lembaga pendidikan agar tercapai visi dan misi lembaga pendidikan dengan tetap memperhatikan kebijakan nasional.

\section{d. Prinsip dan Fungsi Manajemen Kurikulum}

Adapun prinsip yang harus diperhatikan dalam melaksanakan manajemen kurikulum sebagai berikut:

1) Produktivitas, hasil yang akan diperoleh dalam kegiatan kurikulum merupakan aspek yang harus

\footnotetext{
${ }^{33}$ Syafaruddin, Manajemen Lembaga, h.
}

dipertimbangkan dalam manajemen kurikulum. Pertimbangan bagaimana agar peserta didik dapat mencapai hasil belajar sesuai dengan tujuan kurikulum harus menjadi sasaran dalam manajemen kurikulum.

2) Demokratisasi, pelaksanaan manajemen kurikulum harus berasaskan pada demokrasi yang menempatkan pengelola, pelaksana dan subjek didik pada posisi yang seharusnya dalam melaksanakan tugas dengan penuh tanggung jawab untuk mencapai tujuan kurikulum.

3) Kooperatif, untuk memperoleh hasil yang diharapkan dalam kegiatan manajemen kurikulum perlu adanya kerjasama yang positif dari berbagai pihak yang terlibat.

4) Efektivitas dan efisiensi, rangkaian kegiatan manajemen kurikulum harus mempertimbangkan efektivitas dan efisiensi untuk mencapai tujuan kurikulum sehingga kegiatan manajemen kurikulum tersebut memberikan hasil yang berguna dengan biaya, tenaga, dan waktu yang relatif singkat.

5) Mengarahkan visi, misi, dan tujuan yang ditetapkan dalam kurikulum, proses manajemen kurikulum harus dapat memperkuat dan mengarahkan visi, misi, dan tujuan kurikulum. ${ }^{34}$

Ada beberapa fungsi manajemen kurikulum di antaranya sebagai berikut.

1) Meningkatkan efisiensipemanfaatan sumberdaya kurikulum.

2) Meningkatkan keadilan dan kesempatan pada siswa untuk mencapai hasil yang maksimal. Kemampuan yang maksimal dapat

${ }^{34}$ Rusman, Manajemen Kurikulum, op. cit., h. 4. 
dicapai peserta didik tidak hanya melalui kegiatan intrakurikuler, tetapi juga perlu melalui kegiatan ekstrakurikuler dan kokurikuler yang dikelola secara integritas dalam mencapai tujuan kurikulum.

3) Meningkatkan relevansi dan efektivitas pembelajaran sesuai dengan kebutuhan peserta didik maupun lingkungan sekitar peserta didik. Kurikulum yang dikelola secara efektif dapat memberikan kesempatan dan hasil yang relevan dengan kebutuhan peserta didik maupun lingkungan sekitar.

4) Meningkatkan efektivitas kinerja guru maupun aktivitas siswa dalam mencapai tujuan pembelajaran. Pengelolaan kurikulum yang profesional, efektif dan terpadu dapat memberikan motivasi pada kinerja guru maupun aktivitas siswa dalam belajar.

5) Meningkatkan efisiensi dan efektivitas proses belajar mengajar. Proses pembelajaran selalu dipantau dalam rangka melihat konsistensi antara desain yang telah direncanakan dengan pelaksanaan pembelajaran.

Sementara itu, Hamalik menyebutkan bahwa manajemen kurikulum harus dikaitkan dengan perkembangan komponen yang mendasari perencanaan dan pengembangan kurikulum. Komponenkomponen itu adalah: perkembangan tujuan pendidikan; (2) perkembangan teori belajar; perkembangan siswa; perkembangan kultur; dan perkembangan bentuk kurikulum yang digunakan. $^{35}$

35 Oemar Hamalik, Manajemen
Dari pendapat-pendapat di atas dapat dipahami bahwa penerapan manajemen kurikulum dilakukan guna memberikan hasil yang lebih efektif, efisien, dan optimal dalam memberdayakan berbagai sumber dan komponen kurikulum. Pencapaian hasil yang efektif, efisien, dan optimal didukung dengan keterlibatan masyarakat dalam pengelolaan kurikulum.

\section{Konsep Sekolah Unggul}

\section{a. Pengertian Sekolah Unggul}

Konsep sekolah unggul dapat diketahui dari unsur input, proses, dan output pendidikan. Qomar mendefenisikan bahwa sekolah unggul adalah sekolah yang memiliki keadaan input baik, keadaan proses sangat baik, dan keadaan output unggul atau istimewa. Tabel beri kut memberikan gambaran korelasi antara input, proses, dan output serta usaha memproses peserta didik menjadi lebih baik. Thomas Jafferson dalam pernyataannya sebagaimana dikutip oleh Soedjiarto, menyatakan "There is nothing more unequal than equal treatment of unequal people”.Pernyataan ini mengindikasikan bahwa dalam proses pendidikan diperlukan adanya perlakuan yang berbeda bagi masing-masing peserta didik. Perlakuan ini dikarenakan adanya asumsi bahwa setiap peserta didik tidak sama dalam kemampuan atau dengan kata lain memiliki perbedaan individu (individual differences). ${ }^{36}$

Pengembangan Kurikulum (Bandung: Remaja Rosdakarya, 2006), h. 14

${ }^{36}$ Soedjiarto, "Pendidikan Dalam Sistem Pendidikan Nasional," dalam Muhammad Ali, Ilmu dan Aplikasi Pendidikan, cet. 3 (Bandung: Imperial Bhakti Utama, 2009), h. 9. 
Konsep wawasan keunggulan menjadi dasar pelaksanaan pendidikan berbasis keunggulan. Dalam praktiknya, pendidikan berbasis keunggulan berbentuk program percepatan, program khusus, program kelas khusus, dan program pendidikan khusus yang merefleksikan pendidikan keunggulan. Hal ini termuat dalam Keputusan Menteri Pendidikan dan Kebudayaan Nomor 0487/U/1992 pasal 15.

Istilah sekolah unggul pertama kali diperkenalkan oleh mantan Menteri Pendidikan dan Kebudayaan Wardiman Djojonegoro pada tahun 1994. Istilah sekolah unggul lahir dari satu visi yang jauh menjangkau ke depan, wawasan keunggulan. Sebagaimana dikutip oleh Bafadal, menurut Wardiman selain mengharapkan terjadinya distribusi ilmu pengetahuan, dengan membuat sekolah unggul di tiap-tiap provinsi, peningkatan sumberdaya manusia menjadi sasaran berikutnya. Lebih lanjut, Wardiman menambahkan bahwa kehadiran sekolah unggul bukan untuk diskriminasi, tetapi untuk menyiapkan sumberdaya manusia yang berkualitas dan memiliki wawasan keunggulan.

Dalam konteks yang luas, Syafaruddin mendefinisikan sekolah unggul sebagai "sekolah yang semua sumberdaya, proses, dan lulusannya memiliki kualitas tinggi dibanding dengan sekolah lainnya dalam jenis, jenjang dan program yang berbeda atau sama."37

Menurut Townsend sebagaimana dikutip Syafaruddin, menyatakan bahwa

37 Syafaruddin, "Komunikasi Untuk Keunggulan Sekolah,” dalam Syafaruddin dan Mesiono (ed.), Pendidikan Bermutu Unggul (Bandung: Citapustaka Media, 2006), h. 96-100 beberapa faktor yang menentukan sekolah menjadi sekolah unggul, yaitu: (1) kepemimpinan;

(2) pengambilan keputusan; (3) keteiibatan stakeholders pendidikan; (4) alokasi sumberdaya; (5) implementasi kurikulum; (6) lingkungan sekolah, iklim, dan budaya dan komunikasi. Sekolah unggul memiliki karakteristik yaitu: (1) pembelajaran didesain dengan berorientasi pada karya; (2) guru dilibatkan dalam perencanaan dan ada pengawasan serta koordinasi oleh guru senior; (3) memiliki sistem reward terhadap prestasi; (4) siswa diarahkan untuk bertanggung jawab terhadap pemeliharaan fasilitas sekolah; (5) tugas yang diberikan kepada siswa ditindaklanjuti dengan cepat; (6) tercipta iklim dan etos kerja yang baik.

Sidi mengemukakan bahwa terdapat empat faktor yang melatarbelakangi perlunya keberadaan sekolah unggulan. Keempat faktor tersebut adalah sebagai berikut.

1) Tantangan untuk meningkatkan nilai tambah (added value), yaitu bagaimana meningkatkan nilai tambah dalam rangka meningkatkan produktivitas nasional, pertumbuhan dan pemerataan ekonomi, sebagai upaya untuk memelihara dan meningkatkan pembangunan berkelanjutan.

2) Tantangan untuk melakukan pengkajian secara komprehensif dan mendalam terhadap terjadinya transformasi struktur masyarakat, dari masyarakat agraris ke masyarakat modern, menuju ke masyarakat industri yang menguasai teknologi dan informasi, yang implikasinya pada tuntutan dan pengembangan sumberdaya manusia (SDM).

3) Tantangan dalam persaingan global 
yang semakin ketat, yaitu bagaimana meningkatkan daya saing bangsa dalam menghasilkan karya-karya yang bermutu dan mampu bersaing sebagai hasil penguasaan ilmu pengetahuan, teknologi, dan seni.

4) Munculnya kolonialisme baru di bidang iptek dan ekonomi menggantikan kolonialisme politik. dengan demikian kolonialisme kini tidak lagi berbentuk fisik, melainkan dalam bentuk informasi. Ketergantungan bangsa kita pada bangsa lain merupakan suatu bentuk kolonialisme baru yang menjadi semacam virtual enemy yang telah masuk ke seluruh pelosok dunia ini. Semua tantangan ini menuntut sumberdaya manusia Indonesia agar meningkatkan serta mempeluas pengetahuan dan wawasan keunggulan, keahlian yang profesional, keterampilan dan kualitasnya. ${ }^{38}$

Departemen Pendidikan dan Kebudayaan, sebagaimana dikutip oleh Suhartono dan Ngadirun, memberikan definisi sekolah unggulan sebagai berikut: Sekolah yang dikembangkan untuk mencapai keunggulan yang dihasilkan (output) dari pendidikannya. Hal ini berarti bahwa sekolah unggulan dikembangkan sebagaimana sekolah konvensional lain yang telah berkembang selama ini dengan memberikan perlakuan yang standar kepada semua peserta didik. ${ }^{39}$

Berdasarkan petunjuk pengelenggaraan sekolah unggulan yang dikeluarkan oleh Departemen Pendidikan dan

38 Indra Djati Sidi, Menuju Masyarakat Belajar (Jakarta: Paramadina, 2001), h. 42-43

39 Suhartono dan Ngadirun, "Penyelenggaraan Program Kelas Unggulan di Sekolah Dasar,” dalam Jurnal Pendidikan, vol. 6, no. 2, h. 117.
Kebudayaan, sebagaimana dikuti oleh Suhartono dan Ngadirun, sekolah unggulan harus memiliki karakteristik berikut.

1) Masukan diseleksi secara ketat dengan menggunakan kriteria yang dapat dipertanggungjawabkan.

2) Sarana dan prasarana menunjang untuk pemenuhan kebutuhan belajar dan penyaluran minat dan bakat siswa.

3) Lingkungan belajar yang kondusif untuk berkembangnya potensi keunggulan menjadi keunggulan yang nyata.

4) Memiliki kepala sekolah dan tenaga kependidikan yang unggul, baik dari segi penguasaan materi pelajaran, metode mengajar, maupun komitmen dalam melaksanakan tugas.

5) Kurikulum yang diperkaya, yaitu melakukan pengembangan dan improvisasi kurikulum secara maksimal sesuai dengan tuntutan belajar.

6) Rentang waktu belajar sekolah yang lebih panjang dibandingkan sekolah lain dan tersedianya asrama yang memadai.

7) Proses pembelajaran yang berkualitas dan hasilnya selalu dapat dipertanggungjawabkan kepada siswa, lembaga, maupun masyarakat.

8) Adanya perlakukan tambahan di luar kurikulum, program pengayaan dan perluasan, pengajaran remedial, pelayanan bimbingan dan konseling yang berkualitas, pembinaan kreativitas, dan disiplin, sistem asrama, serta kegiatan ekstra kurikuler lainnya.

9) Pembinaan kemampuan kepemimpinan yang menyatu dalam keseluruhan sistem pembinaan siswa melalui praktik langsung dalam 
kehidupan seharihari.

Secara khusus sekolah unggulan bertujuan untuk menghasilkan output pendidikan yang memiliki keunggulan dalam hal :

1) Keimanan dan ketaqwaan kepada Tuhan Yang Maha Esa.

2) Nasionalisme dan patriotosme yang tinggi.

3) Wawasan Iptek yang mendalam dan luas.

4) Motivasi dan komitmen yang tinggi untuk mencapai prestasi dan keunggulan.

5) Kepekaan sosial dan kepemimpinan.

6) Disiplin yang tinggi yang ditunjang kondisi fisik yang prima ${ }^{40}$

\section{b. Pengertian Kelas Unggulan}

Pendidikan bagi anak berbakat dapat dilaksanakan dengan berbagai model, seperti akselerasi, pengayaan, dan pengelompokan berdasarkan kemampuan. Model akselerasi atau percepatan dapat dilaksanakan dalam berbagai bentuk, yaitu memasuki sekolah dasar pada usia dini, loncat kelas, pelayanan individual, dan mengikuti proses pembelajaran di kelas yang lebih tinggi. Melalui model ini para siswa memiliki peluang untuk dapat menyelesaikan pendidikannya dalam waktu lebih singkat.

Model pengayaan (enrichment) adalah model pendidikan siswa yang berkemampuan unggul dengan cara memberikan tugas-tugas tambahan yang relevan dengan bidang studi yang diterimanya. Tugas-tugas tambahan itu, seperti membaca buku-buku yang isinya relevan dengan mata pelajaran yang sedang dipelajari dan

${ }^{40}$ Moedjiarto, Sekolah Unggul (Surabaya: Duta Graha Pustaka, 2002), h. 34. mengerjakan soal-soal tambahan.

Model pengelompokan berdasarkan kemampuan (cluster grouping) dilakukan dengan mengelompokkan siswa berdasarkan kemampuan. Siswa diidentifikasi berbakat dari semua tingkatan kelas yang sama di satu sekolah dikelompokkan ke dalam satu kelas. Kelompok tersebut terdiri atas lima atau delapan siswa. Jika lebih dari delapan anak, sebaiknya mereka dikelompokkan menjadi dua kelompok. Setiap kelompok siswa dibimbing oleh seorang guru yang memiliki kemampuan atau keterampilan khusus untuk mengajar atau membimbing para siswa yang berkemampuan luar biasa. Pada umumnya, satu kelompok siswa berbakat ini belajar bersama-sama dengan siswa lain yang beragam kemampuannya, tetapi dalam bidang keluarbiasaannya (misalnya matematika), mereka belajar secara terpisah. ${ }^{41}$

Secara khusus, pelaksanaan program kelas unggulan memiliki dasar hukum:

1) Undang- Undang Republik Indonesia Nomor 20 Tahun 2003 tentang Sistem Pendidikan Nasional.

2) Peraturan Pemerintah Nomor 19 Tahun 2005 tentang Standar Nasional Pendidikan.

3) Peraturan Menteri Pendidikan Nasional Nomor 34 Tahun 2006 tentang Pembinaan Prestasi Peserta Didik yang Memiliki Potensi Kecerdasan dan/atau Bakat Istimewa.

4) Keputusan Menteri Pendidikan dan Kebudayaan Nomor 0487/U/1992.

5) Kebijakan Departemen Pendidikan

${ }^{41}$ Syamsu Yusuf LN, "Pendidikan Anak Berbakat," dalam Muhammad Ali, Ilmu dan Aplikasi Pendidikan, cet. 3 (Bandung: Imperial Bhakti Utama, 2009), h. 170-171. 
Nasional tahun 2007 tentang pedoman Penjaminan Mutu Sekolah/madrasah Bertaraf Internasional pada jenjang Pendidikan Dasar dan Menengah. ${ }^{42}$

Pada awalnya kebijakan penyelenggaraan kelas unggulan dimulai pada jenjang pendidikan dasar. Program kelas unggulan merupakan program khusus untuk mengelompokkan siswa berdasar prestasi yang tinggi atau bakat istimewa. Kelas unggulan dirancang untuk memberikan pelayanan belajar yang memadai bagi siswa yang benar-benar mempunyai kemampuan yang luar biasa. Pemberian pelayanan pembelajaran khusus tersebut dilakukan agar potensi anak berbakat dapat berkembang secara optimal. Kelas unggulan dikembangkan untuk mencapai keunggulan dalam keluaran (output) pendidikan sebagai sekolah model dalam rangka peningkatan mutu pendidikan. Untuk mencapai keunggulan tersebut, maka masukan (siswa, guru, cara pengeloaan, dan proses pembelajaran) harus diarahkan untuk menunjang tercapainya tujuan tersebut. ${ }^{43}$

$$
\text { Melalui kelas unggulan, }
$$
sejumlah siswa yang karena prestasinya menonjol, dikelompokkan di dalam kelas tertentu. Pengelompokan ini dimaksudkan untuk membina siswa dalam mengembangkan kecerdasan, kemampuan, keterampilan, dan potensinya seoptimal mungkin sehingga memiliki pengetahuan, keterampilan, dan sikap yang terbaik sebagaimana

\footnotetext{
42 Ibrahim Bafadal, Peningkatan Profesionalisme Guru Sekolah Dasar Dalam Kerangka Manajemen Peningkatan Mutu Berbasis Sekolah (Jakarta: Bumi Aksara, 2003), h. 27.

${ }^{43}$ Suhartono dan Ngadirun, Jurnal Pendidikan, h. 115.
}

semangat konsep wawasan keunggulan.

Secara rinci, tujuan pengembangan kelas unggulan adalah sebagai berikut.

1) Mempersiapkan siswa yang cerdas, beriman dan bertakwa kepada Tuhan yang Maha Esa, memiliki budi pekerti yang luhur, memiliki pengetahuan dan keterampilan serta sehat jasmani dan rohani.

2) Memberikan kesempatan kepada siswa yang memiliki kecerdasan di atas rata-rata normal untuk mendapatkan pengetahuan dan keterampilan yang sesuai dengan potensinya.

3) Memberikan kesempatan kepada siswa agar lebih cepat mentransfer ilmu pengetahuan dan teknologi yang diperlukan sesuai dengan perkembangan pembangunan.

4) Memberikan penghargaan kepada siswa yang berprestasi baik.

5) Mempersiapkan lulusan kelas unggulan menjadi siswa unggulan dalam bidang pengetahuan dan teknologi sesuai dengan perkembangan mental siswa. ${ }^{44}$

Apabila merujuk kepada rumusan tujuan, khususnya rumusan tujuan nomor dua dan empat di atas, pembentukan kelas unggulan diperuntukkan bagi siswa yang memiliki kecerdasan di atas rata-rata normal atau yang berprestasi untuk mendapatkan pengetahuan dan keterampilan sesuai dengan potensinya. Karena itu, dalam rangka pengembangan kelas unggulan harus dilakukan penjaringan dan penyaringan siswa yang memiliki prestasi.

h. 29. 
Penjaringan dan penyaringan dilakukan dengan cara menelusuri minat, bakat, dan prestasi siswa.

Dengan demikian dapat disimpulkan bahwa dalam proses penentuan, penyeleksian dan penetapan siswa kelas unggulan, sekolah perlu mempersiapkan sistem rekrutmen siswa. Keberadaan psikolog baik secara pribadi maupun lembaga dalam menyeleksi bakat dan minat siswa kelas unggulan melalui tes kemampuan mutlak diperlukan. Untuk mencapai hasil tes kemampuan yang baik diperlukan alat seleksi yang telah terstandar. Kesemuanya itu menjadi tanggung jawab sekolah terkait dengan pelaksanaan program kelas unggulan.

\section{c. Kurikulum pada Kelas Unggulan}

Dalam penyusunan kurikulum perlu diperhatikan asas-asas kurikulum. Asasasas ini menjadi dasar dalam penyusunan kurikulum. Nasution menyatakan bahwa terdapat empat asas kurikulum, yaitu: 1) asas filosofis, 2) asas psikologis, 3) asas sosiologis, dan 4) asas organisatoris. Berkaitan dengan hal ini, kurikulum pada kelas unggulan disusun atas asas-asas tersebut di atas.

Salah satu asas yang mendominasi dalam penyusunan kurikulum kelas unggulan adalah asas psikologis. Pada asas psikologis, aspek psikologi peserta didik dan aspek psikologi belajar merupakan dua aspek utama. Dari aspek psikologi peserta didik, kurikulum yang disusun disesuaikan untuk kepentingan peserta didik agar tercipta suasana pembelajaran yang menjamin berkembangnya bakatnya. Dari aspek psikologi belajar, kurikulum yang disusun dengan pertimbangan bahwa peserta didik pada hakikatnya dapat dipengaruhi kelakuannya untuk belajar.

Hemat penulis, pendapat di atas berimplikasi pada kurikulum kelas unggulan. Implikasinya adalah bahwa kurikulum kelas unggulan memiliki perbedaan dengan kurikulum kelas reguler (non-unggulan). Perbedaan tersebut dapat terletak pada pengembangan materi ajar, metode, sumber belajar, indikator pembelajaran, kompetensi pembelajaran, evaluasi, dan sebagainya. Kurikulum kelas unggulan disusun dan dikembangkan sesuai dengan perkembangan bakat peserta didik.

Siswa kelas unggulan merupakan siswa yang dikategorikan sebagai siswa berbakat istimewa, yaitu siswa yang memiliki kemampuan jasmani, rohani, cerdas, kreatif, inovatif, dan berkepribadian luhur. Untuk itu siswa yang akan mengikuti program kelaskelas unggulan harus diseleksi secara ketat. Jumlah siswa kelas unggulan maksimal 30 orang. Bagi program kelas unggulan, Syafaruddin mengemukakan bahwa penerapan kurikulum yang optimal dengan dukungan sumberdaya yang ada akan mendorong peningkatan kinerja sekolah dalam wujud lulusan yang unggul dan kepuasan kerja personil sekolah serta masyarakat. Selanjutnya, terkait dengan hal di atas, Syafaruddin menyatakan bahwa:

Ada beberapa persoalan dalam pelaksanaan kurikulum yang harus diperhatikan, yaitu: (1) kualitas program yang diberikan; (2) guru yang dilibatkan dalam proses pembelajaran; (3) harapan yang diberikan oleh warga sekolah; (4)pengembangan teknik motivasi dan penggunaannya oleh sekolah untuk mencapai harapan; (5) alokasi waktu terhadap keragaman mata pelajaran atau aktivitasnya; (6) jenis pembelajaran yang digunakan (kelas, kelompok dan praktik, laboratorium); dan (7) cara 
memajukan pelajar melalui program
pemantauan.

Dalam mempersiapkan kurikulum untuk siswa kelas unggulan perlu ditempuh cara-cara sebagai berikut.

1) Pengembangan bahan pelajaran.

2) Mengembangkan strategi mengajar.

3) Penyusunan sistem evaluasi yang sesuai.

4) Membuat program bimbingan dan penyuluhan yang efektif bagi siswa kelas unggulan.

5) Pengembangan sistem administrasi dan supervisi pendidikan yang sejalan dengan strategi belajar mengajar dan sistem evaluasi dan bimbingan konseling yang telah dikembangkan.

6) Peningkatan kemampuan tenaga kependidikan/ guru yang relevan dalam melaksanakan program ini.

7) Mewujudkan lingkungan belajar/ sekolah yang dapat membantu perkembangan siswa kelas unggulan.

8) Melengkapi sarana/ fasilitas pendidikan yang menunjang terwujudnya tujuan ini.

Kelas unggulan mendapat kurikulum plus dan nilai tambah dibandingkan dengan kelas-kelas lainnya berupa pengajaran dan pelatihan tambahan. Tujuan dari pelaksanaan ini untuk menonjolkan keunggulan yang dimiliki oleh siswa kelas unggulan. ${ }^{46}$ Untuk melayani kebutuhan pendidikan siswa pada kelas unggulan diperlukan

45 Syafaruddin, "Komunikasi Untuk Keunggulan Sekolah” dalam Syafaruddin dan Mesiono (ed.), Pendidikan Bermutu Unggul, h. 99.

46 Anita Lie, Cooperative Learning: Mempraktikkan Cooperative Learning di Ruang-Ruang Kelas, cet. 7 (Jakarta: Grasindo, 2010), h. 40. kurikulum berdiferensiasi. Kurikulum berdiferensiasi merupakan kurikulum yang diberikan untuk memenuhi kebutuhan pendidikan siswa berbakat atau unggul yang memiliki minat dan kemampuan istimewa. Dasar pertimbangan dari asas-asas kurikulum berdiferensiasi adalah bahwa perubahan kurikulum diperlukan karena perbedaan karakteristik dan kebutuhan belajar, emosional, dan sosial dari siswa berbakat. Maker sebagaimana dikutip oleh Munandar menyatakan bahwa kurikulum untuk siswa berbakat atau unggul memerlukan modifikasi dalam empat bidang, yaitu materi (content) yang diberikan, proses atau metode pembelajaran, produk yang diharapkan dari siswa, dan lingkungan belajar. $^{47}$

Agar program siswa berbakat atau unggul berhasil, diperlukan lingkungan yang berpusat pada siswa. Untuk membuat modifikasi dari lingkungan kelas tradisional yang berpusat pada guru ke lingkungan yang berpusat pada siswa, diperlukan modifikasi dari prosedur belajar dan pembelajaran. Parke sebagaimana dikutip oleh Munandar, menyatakan ciri-ciri lingkungan yang berpusat kepada siswa. Ciri- ciri lingkungan tersebut adalah sebagai berikut.

1) Siswa menjadi mitra dalam membuat keputusan tentang kurikulum.

2) Pola duduk yang memudahkan belajar.

3) Kegiatan dan kesibukan di dalam kelas.

4) Rencana belajar yang diindividualkan.

5) Keputusan dibuat bersama oleh guru

47 Utami Munandar, Pengembangan Kreativitas Anak Berbakat, cet. 3 (Jakarta: Departemen Pendidikan Nasional bekerjasama dengan Rineka Cipta, 2009), h. 138. 
dan siswa jika mungkin.

Selanjutnya, Munandar mengemukakan tentang siapa saja yang dapat menjadi guru untuk siswa berbakat istimewa atau unggul. Menurutnya, ada empat macam tokoh yang dapat dijadikan guru untuk siswa berbakat istimewa atau unggul, yaitu:

1) Mentor pada program siswa berbakat istimewa

2) Mentor adalah narasumber, biasanya dari masyarakat yang dapat memberi pengalaman pendidikan tambahan dalam salah satu bidang keahlian. Misalnya seorang analisis komputer, seorang seniman, atau seorang yang ahli dalam geografi perkotaan.

3) Orangtua, Orangtua berperan dalam memberikan informasi mengenai anaknya untuk membantu menentukan minat, kemampuan, kebutuhan, dan perkembangan siswa berbakat istimewa atau unggulan. Orangtua membantu guru dalam menyelenggarakan proyek individual, program mentor, kelompok minat khusus, dan karya wisata.

4) Psikolog, Psikolog dapat mendukung program siswa berbakat istimewa atau unggulan dengan membantu orangtua menghadapi kebutuhan dan minat khusus siswa berbakat istimewa atau unggulan dan membantu mengidentifkasi keberbakatan siswa.

5) Konselor, Konselor dapat membantu siswa berbakat istimewa atau unggul untuk belajar lebih memahami diri sendiri dan untuk mengambil keputusan yang bijak, baik dalam menentukan mata pelajaran pilihan atau dalam bidang pilihan karier. Caranya adalah dengan mengadakan sidang bersama antara orangtua, guru, dan konselor.
Dari kutipan di atas dapat dipahami bahwa kurikulum pada kelas unggulan dimodifikasi dengan pertimbangan adanya perbedaan individu (individual differences) yang dimiliki oleh siswa kelas unggulan. Dalam pelaksanaan kurikulum siswa kelas unggulan diperlukan keterlibatan berbagai pihak mulai dari kalangan internal sekolah (kepala sekolah, wakil kepala sekolah, guru, staf pegawai) dan kalangan eksternal sekolah (komite sekolah, mentor, psikolog, dan orangtua siswa).

\section{A. Penutup}

Berdasarkan deskripsi data dan analisis yang penulis paparkan maka dapat ditarik benang merah tulisan ini sebagai berikut:

1. Penerapan manajemen kurikulum pada kelas ungulan merupakan hal yang esensial karena penerapan kurikulum menjadi salah satu faktor dalam pengaktualisasian potensi peserta didik. Dengan pertimbangan bahwa kelas unggulan merupakan kelas yang di dalamnya terdapat peserta didik yang berbakat. Sekolah/madrasah sebagai lembaga pendidikan formal yang berciri khas Islam peiu memfasilitasi pengadaan kelas unggulan yang ideal. Idealnya suatu kelas unggulan diukur dari pemenuhan standar nasional pendidikan yang berhubungan dengan manajemen kurikulum.

2. Program kelas unggulan dirancang berdasarkan konsep dan sistem pembelajaran yang mengedepankan upaya penggalian potensi dan bakat serta minat setiap siswa yang beraneka ragam (individual differences based learning) secara khusus untuk diberikan pelayanan 
pendidikan secara komprehensif, efektif dan terarah.

3. Program kelas unggulan telah menunjukkan kemajuan dan prestasi yang membanggakan baik secara akademis maupun non akademis serta lulusannya dapat diterima di perguruan tinggi negeri favorit di tanah air maupun pendidikan tinggi ikatan dinas. Disamping secara progresif yang tiada henti terus berupaya melakukan berbagai perbaikan dan inovasi pendidikan sehingga program ini mampu menjadi pilot program yang lebih unggul di masa depan menuju sekolah/ madrasah dengan pelayanan internasional.

4. Kelas unggulan merupakan kelas yang dibentuk secara khusus dan berkarakteristik, mulai dari penyeleksian siswa, pembelajaran, cakupan pelajaran, nilai kriteria ketuntasan minimal (KKM) yang lebih tinggi, jam pelajaran, jumlah siswa dalam kelas dan fasilitas kelas yang disediakan dengan tujuan pelayanan proses pembelajaran untuk peserta didik yang mempunyai potensi, minat dan bakat yang lebih agar berkembang secara optimal dalam proses kegiatan belajar mengajar (KBM).

5. Perencanaan kurikulum kelas unggulan di sekolah/ madrasah disusun dengan melibatkan tim pengembang kurikulum yang terdiri dari kepala sekolah/ madrasah, wakil- wakil kepala sekolah/ madrasah, guru, komite sekolah/ madrasah, tenaga ahli dari dewan pakar Sekolah/ madrasah, dan orang tua siswa. Langkah yang dilakukan adalah dengan menganalisis konteks dan kebutuhan serta mengidentifikasi standar nasional pendi- dikan. Kepala sekolah/ madrasah bersama tim pengembang kurikulum menyusun dokumen satu menentukan visi, misi, tujuan sekolah/ madrasah, struktur dan muatan kurikulum dan kalender pendidikan.

6. Faktor pendukung yang utama dalam penerapan manajemen kurikulum kelas unggulan di Sekolah/ madrasah adalah kerja sama tim pengembang kurikulum dan kerja sama antarguru dalam wadah MGMP, jenjang pendidikan guru kelas unggulan yang sesuai dengan dan jurusan mata pelajaran yang diajarkan, peranan komite sekolah/madrasah yang proaktif, dan ketersedian sarana dan prasarana yang memadai. Faktor penghambat penerapan manajemen kurikulum kelas unggulan adalah tanggung jawab akademik tenaga pengajar yang masih kurang, motivasi guru yang mengajar pada kelas unggulan, kesiapan siswa secara psikologis mengikuti pembelajaran, dan kurangnya pengawasan dari dewan pakar Sekolah/ madrasah terhadap pelaksanaan kurikulum di kelas unggulan.

\section{DAFTAR PUSTAKA}

Ali Idrus, Manajemen Pendidikan Global: Visi, Aksi dan Adaptasi Jakarta: Gaung Persada Press, 2009

Ali Idrus, Manajemen Pendidikan Global: Visi, Aksi dan Adaptasi Jakarta: Gaung Persada Press, 2009

Anita Lie, Cooperative Learning: Mempraktikkan Cooperative Learning di Ruang-Ruang Kelas, cet. 7 Jakarta: Grasindo, 2010

Anton Athoillah, Dasar-Dasar Manajemen 
Bandung: Pustaka Setia, 2010

Bedjo Sujanto, Guru Indonesia dan Perubahan Kurikulum Jakarta: Sagung Seto, 2007

Departemen Pendidikan Nasional, Manajemen Berbasis Sekolah Jakarta: Dirjen Dikdasmen Direktorat Tenaga Kependidikan, 2003

Djam'an Satori dan Suryadi, “Teori Administrasi Pendidikan,” dalam Muhammad Ali, Ilmu dan Aplikasi Pendidikan, cet. 3 Bandung: Imperial Bhakti Utama, 2009

Ibrahim Bafadal, Manajemen Peningkatan Mutu Sekolah Dasar dari Sentralisasi Menuju Desentralisasi Jakarta: Bumi Aksara, 2003

Ibrahim Bafadal, Peningkatan Profesionalisme Guru Sekolah Dasar Dalam Kerangka Manajemen Peningkatan Mutu Berbasis Sekolah Jakarta: Bumi Aksara, 2003

Indra Djati Sidi, Menuju Masyarakat Belajar Jakarta: Paramadina, 2001

J. Salusu, Pengambilan Keputusan Stratejik untuk Organisasi Publik dan Organisasi Nonprofit, cet. 4 Jakarta: Grassindo, 2002

Lexy J. Moleong, Metodologi Penelitian Kualitatif, Bandung: CV. Rosdakarya, 2006

Made Pidarta, Manajemen Pendidikan Indonesia, cet. 1 Jakarta: Rineka Cipta, 2011

Malayu S.P. Hasibuan, Manajemen: Dasar, Pengertian, dan Masalah Jakarta: Bumi Aksara, 2006

Marno, Islam by Management and Leadership Jakarta: Lintas Pustaka Publisher, 2007

Moedjiarto, Sekolah Unggul Surabaya:
Duta Graha Pustaka, 2002

Muhaimin, et.al., Manajemen Pendidikan: Aplikasinya dalam Penyusunan Rencana Pengembangan Sekolah/Madrasah, cet. 3 Jakarta: Kencana, 2011

Mujamil Qomar, Manajemen Pendidikan Islam Jakarta: Erlangga, 2007

Mulyasa, Kurikulum Tingkat Satuan Pendidikan, cet. 2 Bandung: Remaja Rosdakarya, 2007

Nana Syaodih Sukmadinata, et.al., Pengendalian Mutu Pendidikan Sekolah Menengah Bandung: Refika Aditama, 2006

Oemar Hamalik, Dasar-Dasar

Pengembangan Kurikulum, cet. 3 Bandung: Remaja Rosdakarya, 2009

Oemar Hamalik, Kurikulum dan Pembelajaran, cet. 8 Jakarta: Bumi Aksara, 2008

$\begin{array}{cr}\text { Oemar Hamalik, } & \text { Manajemen } \\ \text { Pengembangan } & \text { Kurikulum } \\ \text { Bandung: Remaja } & \text { Rosdakarya, } \\ 2006 & \end{array}$

Rusman, Manajemen Kurikulum, cet. 3 Jakarta: Rajawali Pers, 2011

Rusman, Manajemen Kurikulum, cet. 3 Jakarta: Rajawali Pers, 2011

Siskandar, Kurikulum Tingkat Satuan Pendidikan Jakarta: Direktorat Jenderal Peningkatan Mutu Pendidik dan Tenaga Kependidikan Depdiknas, 2008

Soedjiarto, "Pendidikan Dalam Sistem Pendidikan Nasional,” dalam Muhammad Ali, Ilmu dan Aplikasi Pendidikan, cet. 3 Bandung: Imperial Bhakti Utama, 2009

Sudarwan Danim dan Suparno, Manajemen dan Kepemimpinan Transformasional 
Kekepalasekolahan Jakarta: Rineka Cipta, 2009

Suhartono dan Ngadirun, "Penyelenggaraan Program Kelas Unggulan di Sekolah Dasar," dalam Jurnal Pendidikan, vol. 6, no. 2

Syafaruddin, "Komunikasi Untuk Keunggulan Sekolah,” dalam Syafaruddin dan Mesiono ed., Pendidikan Bermutu Unggul Bandung: Citapustaka Media, 2006

Syafaruddin, Manajemen Lembaga Pendidikan Islam Jakarta: Ciputat Press, 2005

Syamsu Yusuf LN, "Pendidikan Anak Berbakat," dalam Muhammad Ali, Ilmu dan Aplikasi Pendidikan, cet. 3 Bandung: Imperial Bhakti Utama, 2009

Umaedi, Manajemen Peningkatan Mutu Berbasis Sekolah Jakarta:

Direktorat Jenderal Pendidikan

Dasar dan Menengah, 2001

Undang-Undang Republik Indonesia Nomor

20 Tahun 2003 bab I pasal 1 ayat 19

Utami Munandar ed., Pengembangan Kreativitas Anak Berbakat, cet. 3 Jakarta: Departemen Pendidikan Nasional bekerja sama dengan Rineka Cipta, 2009

Utami Munandar, Pengembangan Kreativitas Anak Berbakat, cet. 3 Jakarta: Departemen Pendidikan Nasional bekerjasama dengan Rineka Cipta, 2009

Winardi, Kepemimpinan Dalam Manajemen Jakarta: Rineka Cipta, 2000 